MANAGING TODAY AND TOMORROW 
Also by Rosemary Stewart

CHOICES FOR THE MANAGER CONTRASTS IN MANAGEMENT

* HOW COMPUTERS AFFECT MANAGEMENT

* LEADING IN THE NHS: A PRACTICAL GUIDE

* MANAGERS AND THEIR JOBS

THE BOSS: THE LIFE AND TIMES OF THE BRITISH

BUSINESSMAN (with Roy Lewis)

THE DISTRICT ADMINISTRATOR IN THE NATIONAL

HEALTH SERVICE (with Jenny Blake, Peter Smith and Pauline Wingate)

THE REALITY OF MANAGEMENT

* THE REALITY OF ORGANIZATIONS

*Also published by Macmillan 


\section{Managing Today and Tomorrow}

Rosemary Stewart

Fellow in Organizational Behaviour

Templeton College, Oxford 
(C) Rosemary Stewart 1991

Softcover reprint of the hardcover 1st edition 1991

All rights reserved. No reproduction, copy or transmission

of this publication may be made without written permission.

No paragraph of this publication may be reproduced, copied or transmitted save with written permission or in accordance with the provisions of the Copyright, Designs and Patents Act 1988, or under the terms of any licence permitting limited copying issued by the Copyright Licensing Agency, 90 Tottenham Court Road, London WIP 9HE.

Any person who does any unauthorised act in relation to this publication may be liable to criminal prosecution and civil claims for damages.

First published 1991

Published by

MACMILLAN ACADEMIC AND PROFESSIONAL LTD

Houndmills, Basingstoke, Hampshire RG21 2XS

and London

Companies and representatives

throughout the world

ISBN 978-1-349-11863-2 ISBN 978-1-349-11861-8 (eBook)

DOI 10.1007/978-1-349-11861-8

A catalogue record for this book is available from the British Library.

Copy-edited and typeset by Povey/Edmondson

Okehampton and Rochdale, England 


\section{Contents}

Acknowledgements

viii

Introduction

ix

PART I MANAGING: WHAT MAKES IT THE SAME?

1 Managing and Managing the Job 3

What is a managerial job?

Studies of managerial work 4

$\begin{array}{ll}\text { Changes over time } & 7\end{array}$

The effective manager: thinking strategically 13

$\begin{array}{ll}\text { Summary } & 18\end{array}$

Appendix: some definitions of management 19

2 Working in an Organization 22

Common characteristics of organizations 23

Different forms of organizations 31

Different views of organizations 33

Common organizational problems $\quad 35$

Successful organizations $\quad 39$

Summary $\quad 40$

Appendix: some definitions of organization $\quad 41$

3 Managing Other People 44

Creating the right conditions 44

What does 'influencing' involve? 48

The analytical approach $\quad 49$

Not just individuals $\quad 54$

Guidelines for managing other people $\quad 59$

$\begin{array}{ll}\text { Summary } & 60\end{array}$ 
vi Contents

PART II MANAGING: WHAT MAKES IT DIFFERENT?

4 Differences in Managerial Jobs 65

How management jobs differ $\quad 66$

Implications: reducing the mismatches $\quad 74$

$\begin{array}{ll}\text { Summary } & 77\end{array}$

5 Differences in Stakeholders $\quad \mathbf{8 0}$

Types of stakeholders $\quad 82$

Who controls the managers? 91

Summary $\quad 97$

6 National Differences 100

$\begin{array}{ll}\text { What social research has shown } & 102\end{array}$

Implications $\quad 113$

How different? 118

$\begin{array}{ll}\text { Summary } & 118\end{array}$

PART III MANAGING: WHAT IS CHANGING?

7 Managerial Implications of the EC 125

The Community institutions 126

How the EC affects managers' jobs 128

How the EC can affect managers' careers $\quad 140$

Britain: meeting the competitive challenge? 141

Relations with other countries 143

Conclusions 143

Summary 144

8 Managerial Implications of IT 147

$\begin{array}{ll}\text { What is IT? } & 147\end{array}$

The IT revolution? 147

The impact on business 149

Organizational repercussions of IT 151

Too many disappointments $\quad 155$

Improving information management $\quad 157$

Impact on managers $\quad 159$ 
Personal implications $\quad 162$

$\begin{array}{ll}\text { Summary } & 163\end{array}$

9 Changing Organizations 166

The changing nature of business 166

Changes in the composition of employees 172

Changes within organizations 175

How radical are the changes? 182

Conclusions 186

$\begin{array}{ll}\text { Summary } & 187\end{array}$

10 Personal Implications of Changes 191

Changes in careers 193

Managing your career 195

Implications for personal life 196

Summary 205

Index of Names 207

Index of Subjects 210 


\section{Acknowledgements}

I am appreciative of the opportunities provided by the Stanford Centre for Organizational Research at Stanford University to spend a sabbatical term there, in the summer of 1990 , writing the first draft of this book. I am grateful to Professor Dick Scott for extending the invitation and to Lisa Hellreich, the administrator of SCOR, for her ever-ready help. Fortunately, despite the earthquake which caused so much havoc to the business school library at Stanford, that fine campus has a number of other good libraries.

I am grateful to the following colleagues at Templeton College who have read and made suggestions about one or more chapters: Sue Dopson; Jim Dukes, who was especially helpful with a chapter that was causing problems; Michael Earl; Rod Martin; Bim Prodhan; and David Skyrme who was visiting from Digital and who, apart from his knowledge of IT, has a fine editorial ability. I am also grateful to John Bishop of ICI Chemical and Polymers and to Professor Nanette Fondas for their help in reading and commenting on individual chapters. Of course the responsibility for the views expressed, and for the remaining defects, are mine. I also wish to thank Valerie Martin for her willing and efficient help with some of the drearier aspects of preparing a book for the publisher.

ROSEMARy STEWART

The author and publishers are grateful to the following for permission to reproduce copyright material:

Professor Gareth Morgan for extracts from his Riding the Waters of Change (San Fransisco: Jossey Bass, 1988) and Creative Organization Theory (Beverly Hills: Sage, 1989).

Professor Michael E. Porter for an extract from 'Japan isn't Playing by Different Rules', The New York Times, 22 July 1990; adapted from The Competitive Advantages of Nations (New York: The Free Press, 1990). Professor Rosabeth Moss Kanter for extracts from her When Giants Learn to Dance (London: Simon \& Schuster, 1989).

Every effort has been made to contact all the copyright-holders, but if any have been inadvertently omitted the publishers will be pleased to make the necessary arrangement at the first opportunity. 


\section{Introduction}

'The basics of management remain the same'; 'Managing is very different in different jobs, organizations and countries'; 'Management is changing radically'. All three of these statements are true, but most books on management focus on only the first or third statement. This book is unusual in that it takes account of all three; it does so because effective managers increasingly have to understand not only the basics of management, but also how management is changing. Managers are much more mobile than they used to be, so they also have a greater need than in the past to understand where, how and why management differs.

Managing Today and Tomorrow is based on three main sources. First, what social research has discovered about management in practice that is relevant to managers; the approach adopted - but not the language - is that of a social scientist. Second, accounts of the changes that companies are making. Third, the experience of managers, from a wide variety of public and private organizations, whom the author has interviewed for many different research projects. Their views are used to provide some of the practical examples in the text.

Managing Today and Tomorrow is addressed to managers, but it is not a 'how-to-do-it' book. It aims to help managers to improve their effectiveness by developing their understanding of management. It is not an academic text, but it can be used by students to help them to acquire an understanding of the three key aspects of management: the basics, the differences found in different management settings, and the changes affecting management.

Those new to management should find Part I of the book helpful, since it is about the basics of management: 'should' rather than 'will' because managers differ in what they find useful, and some find it hard to learn anything from books. Experienced managers may find that Part I helps them to interpret their previous experience. Parts II and III are potentially relevant to all managers, though a manager's particular setting will determine which are most relevant now. Part II is about the differences within management. Part III is about the changes affecting managers' jobs and careers. There is a separate introduction to 


\section{$\mathrm{x} \quad$ Introduction}

each Part which describes the content of individual chapters within it.

Managing Today and Tomorrow is written as a successor to The Reality of Management; the choice was between another edition or a new book, but the changes are too great for the former. The Reality of Management has been selling for so long that I know which book people mean when they say: 'I have read your book' - though I have published nine others. The Reality of Management is a simpler book than this new study, and so can still be of use. Management is more complex than it was thirty years ago, when The Reality of Management was first written, and a new book must take account of that complexity, and of the greater professionalism now expected of managers. 